\title{
Shrimp Farming as an Alternative to Artisanal Fishermen Communities: the Case of Patos Lagoon, Brazil
}

\author{
Ronaldo Olivera Cavalli ${ }^{1,2 *}$, Wilson Wasielesky $\mathbf{J r}^{1}$, Silvio Peixoto ${ }^{1,2}$, Luís Henrique da \\ Silva Poersch ${ }^{1}$, Marcos Henrique Silva Santos ${ }^{1}$ and Roberta Borda Soares ${ }^{1,2}$ \\ ${ }^{I}$ Departamento de Oceanografia; Estação Marinha de Aqüicultura; Fundação Universidade Federal do Rio \\ Grande; C.P.: 474; 96201-900; Rio Grande - RS - Brasil. ${ }^{2}$ Departamento de Pesca e Aqüicultura; Universidade \\ Federal Rural de Pernambuco; Av. Dom Manoel Medeiros, s/n, Dois Irmãos; 52171-900; Recife - PE - Brasil
}

\begin{abstract}
The shrimp Farfantepenaeus paulensis is considered a suitable species for culture in the Patos Lagoon estuary, southern Brazil, where its catch has been decreasing in the last few years. Considering the potential of estuarine areas for shrimp farming, the application of low-cost structures to culture shrimp, such as the pen enclosures, is being proposed as an alternative source of income for artisanal fishermen and farmers living near Patos Lagoon. From an economical standpoint, these alternative systems present several advantages over the traditional pond-based culture systems since land, water pumping and artificial aerations are not required, high natural productivity is available and inexpensive materials are employed in the construction of grow-out structures. This paper reviews the farming of $\mathrm{F}$. paulensis in the pen enclosures as an alternative to the artisanal fishing communities of the Patos Lagoon estuary. Particular emphases are placed on the development of culture systems, social and environmental impacts, constraints and perspectives.
\end{abstract}

Key words: shrimp farming, alternative culture, pen enclosure, Farfantepenaeus paulensis

\section{INTRODUCTION}

The estuarine area of Patos lagoon was considered one of the most productive fishing areas in Brazil (Castello, 1985). This lagoon, located in southern Brazil, has a surface area of $10,360 \mathrm{~km}^{2}$ and extends over the coastal plain of the state of Rio Grande do Sul. The lagoon measures approximately $250 \mathrm{~km}$ at its longest extent and 60 $\mathrm{km}$ at its greatest width. Although the mean depth varies between 6 and $8 \mathrm{~m}$, in the natural or manmade navigation channels, it increases to $10-20 \mathrm{~m}$. Shallower areas are usually less than $50 \mathrm{~cm}$ deep and up to $3 \mathrm{~m}$ at the most. The southern part of the
Lagoon system joins the Atlantic Ocean via a channel between a pair of breakwaters, which are about $4 \mathrm{~km}$ long and $700 \mathrm{~m}$ apart at the mouth (Castello, 1985). The Patos Lagoon can be considered as a large coastal lagoon, but its connection with the Atlantic Ocean presents great variation of salinity, which makes its southern part an estuary. The estuarine zone usually extends over $1,000 \mathrm{~km}^{2}$. However, winds from the south or southwest can sometimes push the marine waters farther north into the lagoon. The astronomical tides in the lagoon have a short vertical range, reaching $40 \mathrm{~cm}$ at the most, and therefore their influence is practically negligible.

\footnotetext{
* Author for correspondence
} 
An artisanal fishery for crustaceans and finfish has existed in the estuary since the end of the Nineteenth century. Since that time, the export of fish captured from the estuary to the markets in the north of Brazil, and to other countries, constituted an important business (Von Ihering, 1885). The statistics of the landings were first recorded in 1945 and an industrial trawler and purse seine fishery commenced in 1947 (Reis, 1992). In 1967, the reduced-tax investments helped to increase the number of fish processing plants in the city of Rio Grande (Abdallah, 1998). Two years later, the fish started to be imported from the neighboring countries to supply these plants (Reis, 1992). From 1974, the industrial fishing on the area and landings into Rio Grande increased largely because of the end of fishing agreements between Brazil, Argentina and Uruguay. However, a renewal of the agreement between Brazil and Uruguay in the same year allowed mutual fishing to continue until 1978 (Reis, 1992). From then onwards, fishing has been done exclusively in Brazilian waters.

The estuary fishery is strictly artisanal, i.e., the boats are less than $10 \mathrm{~m}$ long and without any shelter. Wooden boats with less than 10 tons of loading capacity, powered with 10-24 horse power motors, and each with a crew of two or three men are used to set the nets and to transport the fish. The fishermen usually set their gear close to their homes or landing sites. The number of fishermen was estimated at around 3,500 (Reis et al., 1994; Reis and D'Incao, 2000).

The landing statistics for the artisanal fishery are unreliable as they are collected at the fishprocessing plants, which mean that the catches loaded directly from the boat to trucks, and those that are taken to other urban centers before being processed are not recorded. Thus, the landing statistics of the artisanal fishery are underestimated and should be treated with caution. Available data, however, indicate that the fish catches in the estuary increased to 40,000 tons in 1966 , but in the 1980's the catches had declined to less than 15,000 tons due to an excess amount of the fishing effort, catches being taken at inappropriate stages of a species' life cycle, environmental pollution, and the use of harmful fishing gears (Reis, 1992). In 1999, the total annual catches were reduced to less than 5,000 tons (CEPERG, 1999). Nowadays, the estuarine fishing does not exist as an economic activity, except for the mullet (Mugil platanus) and pink shrimp (Farfantepenaeus paulensis) (Reis and D'Incao, 2000).

The amount of shrimp captured by the artisanal fishery every year in the estuary is dependant on the amount of rainfall and wind conditions prevailing in the region from late winter to early spring. Because the reproduction and larval development of this species take place in the ocean during the spring, 1-1.5 $\mathrm{cm}$ long shrimp have to be carried into the estuary by water currents. In this sheltered environment, shrimp reach around 8-10 $\mathrm{cm}$ in length within 3 to 5 months (from late spring to early autumn) and then return to the ocean to complete their life cycle (D'Incao, 1991). Heavy rainfall from July to December has been demonstrated to negatively affect the shrimp catch in the estuary in the following year (Castello and Möller, 1978), probably because the number of small shrimp penetrating the estuary is reduced. As a result, the landings of shrimp by the artisanal fishery experience wide annual variations (Fig. 1). In the last few years, however, the catches have tended to decrease due to the excessive fishing effort for both the juveniles in the estuary and the adult population in the adjacent coastal waters (D'Incao et al., 2002). The official opening season for the artisanal fishing of shrimp starts every year in February and continues for as long as the shrimp catches are economically profitable, usually the end of April.

\section{Farming of shrimp as an alternative}

Brazil has long been recognized as having ideal conditions for the development of shrimp farming as it possesses large areas of the coastal land, warm water temperatures year round, an extensive agro-industrial base and an attractive domestic market. The first attempts to farm shrimp at a commercial level were carried out in the northeast in the 1970's with the exotic shrimp Marsupenaeus japonicus. Soon the federal Government agencies began encouraging shrimp farming by providing special financial incentives, but due to the low tolerance of M. japonicus to the local environmental conditions and the lack of expertise and appropriate infrastructure, many projects closed down. 


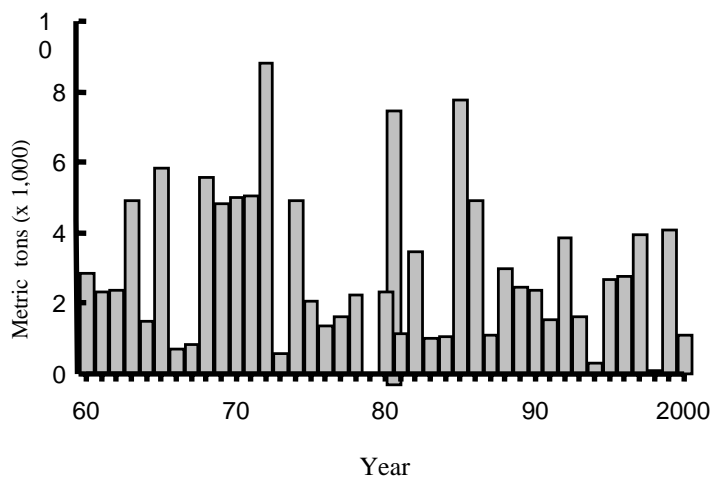

Figure 1 - Landing of shrimp in the Patos Lagoon, Brazil, from 1960 to 2001.

The activity then shifted to the indigenous Farfantepenaeus subtilis and Litopenaeus schmitti, and the exotic Litopenaeus vannamei. However, the production levels and the interest for the activity remained low.

Since 1994, with the improved performance and adaptability of L. vannamei to the local conditions and culture practices, and also due to the improvement of the commercially available feeds, shrimp farming in Brazil has turned from a dormant activity to an important industry. From 1996 to 2001, the area devoted to shrimp culture increased at a rate above $50 \%$ per year (Nunes and Suresh, 2001), making shrimp farming one of the fastest growing agricultural activities in the country. In 2003, 90,190 metric tons were produced in 14,824 ha (ABCC, 2004). However, as this activity is based on the pond-culture of an exotic species (L. vannamei) mainly in large size enterprises, the ecological impacts and social benefits for the local communities deriving from this activity are subject to dispute.

The farming of shrimp has been identified as an alternative source of income for both the artisanal fishermen and farmers living near the estuarine area of Patos Lagoon. However, initial investments for the construction of shrimp ponds are relatively high, making it impractical for communities with limited economical resources. Nevertheless, the application of alternative means for culturing shrimp, such as cage and pen culture, have been proposed in several Asian countries (SEAFDEC, 1979; Peña and Prospero, 1984; Walford and Lam, 1987; Samaranayake, 1990; Tookwinas, 1990) as well as in Brazil (Wasielesky et al., 1995; Paquotte et al.,
1998). From an economical standpoint, the use of these alternative culture systems presents several advantages over the traditional pond-based culture systems. First of all, the land is not required and public waters are used. This is clearly a key strength for the poor and the landless, but it is possible that access to water may be a limiting factor. Furthermore, the working capital requirements are also low because of the small scale of the enterprises and the relatively short production cycle. In addition, initial investments are also low as relatively inexpensive materials are employed in the construction of grow-out structures and no water pumping and aerator devices are required. Finally, high natural productivity within the systems greatly reduces the feeding costs. These factors represent important points in lowering the costs and suggest that shrimp pen culture may be economically feasible as a small-scale activity, requiring modest investments. This may provide artisanal fishing communities the opportunity to culture shrimp and obtain an alternative source of income.

This study presents the farming of $F$. paulensis as an alternative for the artisanal fishing communities of the Patos Lagoon estuary. Particular emphasis is placed on discussing the culture in pen enclosures, social and environmental impacts of this activity and future constraints and possibilities of $F$. paulensis pen culture.

\section{Farming of $f$. paulensis in the patos lagoon}

The estuary of Patos Lagoon is a natural habitat for $F$. paulensis, and hence this species is perfectly adapted to this environment. Furthermore, this estuary is characterized by a high productivity 
(hence a large availability of natural food items), low presence of predators and good water quality. All these conditions make this area well suited for the development of $F$. paulensis farming. Given these environmental conditions and the possibility to provide the fishermen with alternatives to fishing, a pilot project has managed to bring together the fishing communities and the university (Wasielesky et al., 1995, 2002). The main goal of the project is to develop alternative sources of income for the fishermen. Initially, based on the work carried out by the university's aquaculture research group, an alternative shrimp culture system has been devised and, through close participation of the fishermen communities, is proving to be an attractive alternative for this community.

\section{Grow out structures}

The first practical aspect dealt in this project was the development of grow-out structures. To achieve the project's philosophy of accommodating artisanal fishermen, these structures were built with materials that were locally available, durable and could be obtained at no or low-cost. Moreover, structures had to be strong enough to withstand the prevailing environmental conditions, especially wind and water currents. After thorough study, two structures proved their feasibility: the net pen enclosures and floating cages (Dolci et al., 1996; Wasielesky et al., 2001a, 2001b). The pen enclosures are suitable for shallow areas with relatively low water currents, whereas cages are appropriate for the deeper (> 1.5 $\mathrm{m})$ waters. The shrimp reared in the pen enclosures have direct contact with the sediment and thus may feed on naturally occurring benthic organisms. Furthermore, as F. paulensis is a burrowing species, the contact that shrimp have with the sediment in the pen enclosures may be advantageous in terms of behavior and consequently survival and growth rates.

The materials used for construction of the pens and cages included bamboo poles, galvanized wiring, and ropes. The netting material that provided the best results (PVC-coated polyester mesh) has a relatively higher price than alternative materials, but since its durability was estimated to last over eight culture cycles, the relatively higher cost could be spread over many years of use.

In the last few years, much more attention has been given to the pen enclosures due to their lower initial investment and a higher output. Labor also tends to be less intensive in comparison to the cages. At present, a standard pen enclosure is circular and has $3,100 \mathrm{~m}^{2}$ of available area (Fig. 2). The pen was built with as many as 400 bamboo poles and $200 \mathrm{~m}$ of $2.1 \mathrm{~m}$ high netting material with a mesh size of $5 \mathrm{~mm}$. The mesh was fastened at the top and bottom with galvanized wiring and was tied to each bamboo pole with the plastic ropes. The bamboo poles were then forced down in such a way that the mesh was inserted into the sediment for $15-20 \mathrm{~cm}$. Thus, the shrimp could not escape or predators could not penetrate the pen enclosure, and prevailing wind and water currents could not unbury the netting material. Three to four people were able to build one $3,100 \mathrm{~m}^{2}$ pen in two days.

\section{Stocking of postlarvae and culture management} The availability of postlarvae (PL) was an essential requirement for the development of the project. However, as there is a comprehensive knowledge of the biology and culture of $F$. paulensis, it is possible to produce large numbers of PL from either wild (Marchiori and Boff, 1983; Marchiori and Cavalli, 1993; Marchiori, 1996) or domesticated broodstock (Cavalli et al., 1997; Peixoto et al., 2003a, 2004a, 2005). Since production has not yet reached a commercial scale, the laboratory PL provided to the fishermen were still produced at the university's Marine Aquaculture Centre and handed to the fishermen. The fishermen were then responsible for growing them until the harvest size, which is typically around 10-12 g. Stocking of the pens with the PL is commonly done in November-December, when the temperature and salinity levels are above $22^{\circ} \mathrm{C}$ and 5\%, respectively.

However, in those years when salinity levels are below $5 \%$ o due to the low penetration of seawater into the estuary, it may be necessary to postpone the stocking of the PL into the pens until later in the season, as high mortality rates may occur at these extreme environmental conditions (Tsuzuki et al., 2000). The PL are usually stocked in a smaller (200 $\mathrm{m}^{2}$ ) nursery cage or pen (with a mesh opening of 1.5 $\mathrm{mm})$ placed within the larger $\left(3,100 \mathrm{~m}^{2}\right)$ pen (Fig. 2). The shrimp are nursery-reared for four weeks or until the smallest shrimp reach a minimum size of $0.35 \mathrm{~g}$. The shrimp of this size are unable to pass through the $5 \mathrm{~mm}$ mesh opening of the grow-out pens. After reaching the appropriate size, the shrimp are then released into the larger pen. 


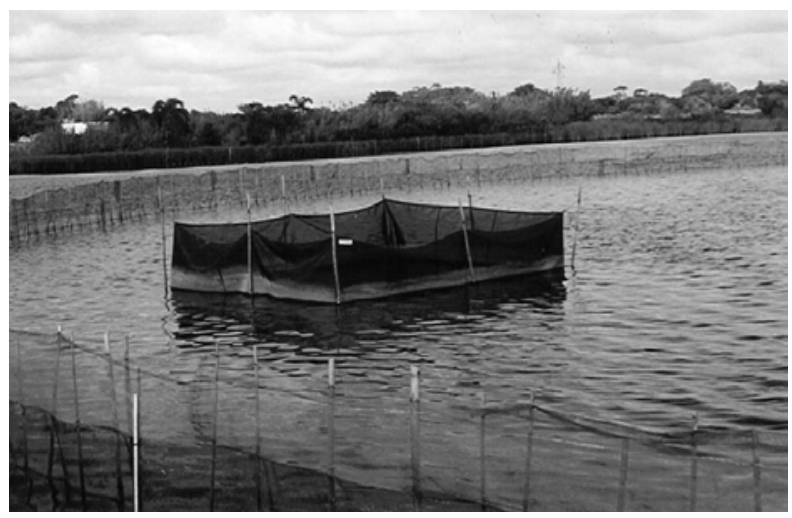

Figure 2 - A 3,100 $\mathrm{m}^{2}$ pen enclosure used for the culture of shrimp (Farfantepenaeus paulensis) in the Patos Lagoon estuary, southern Brazil. Note the smaller nursery rearing pen placed within the larger grow-out enclosure.

While L. vannamei is typically cultured intensively at densities of 40 individuals $\mathrm{m}^{-2}$ (Nunes and Suresh, 2001), the pen culture of $F$. paulensis uses densities ranging from 15 to 30 individuals $\mathrm{m}^{-2}$ (Wasielesky et al., 2001a; Cavalli et al., 2003; Pissetti, 2004). Feeding is carried out daily at the evening and may consist of a commercial shrimp diet and/or a mixture of chopped fish (several species), crab (Callinectes sp.) and shrimp (Artemesia longinaris and $F$. paulensis) heads (Domingos et al., 2000; Santos et al., 2000, 2001). The use of fresh food items in the feeding of $F$. paulensis brings two advantages: higher survival and growth rates in comparison to the commercially available shrimp feeds (Santos et al., 2000) and the utilization of a resource usually discarded by the fishermen and fish processing industries, which can cause serious environmental problems for the region. The culture cycle, including nursery and grow-out, usually lasts for 120-140 days.

\section{Harvest and commercialization}

At the end of the culture cycle, 400 to $500 \mathrm{~kg}$ shrimp are obtained per pen, which means that 1,250-1,600 $\mathrm{kg}$ may be produced per hectare (Wasielesky et al., 2002). For the shrimp caught by the artisanal fisheries, the price paid by the middlemen and the processing industry is usually around US $\$ 1.00$ per $\mathrm{kg}$, but it fluctuates in accordance to the abundance of shrimp in the local market, which in turn is closely related to the success of the artisanal fishing in that particular year. On the other hand, the price of shrimp reared in the pen enclosures may be 2 or 3 times higher because of higher quality of the cultured shrimp. Such economical benefits can be further improved as the harvest times can be planned to take advantage of higher prices for the shrimp which can be obtained at the end of the fishing season. Furthermore, in comparison to the shrimp captured by the artisanal fishery, the cultured shrimp tend to be less variable in size, which is considered an important parameter for the market, and superior in quality in terms of physical, chemical and microbiological parameters (Costa and Prentice, 2003).

An additional attractiveness of the pen cultured shrimp is that the producers can obtain an "organic shrimp label" through the certification by nationally recognized institutions (Cavalli et al., 2005). This label would not only increase the value of the final product, but also enforce and serve as an example of the importance of the postharvest procedures and direct commercialization by the fishermen.

An economic analysis assessed the feasibility of $F$. paulensis farming in the pen enclosures (Abdallah et al., 2003). Because feed was the most expensive item among the operational costs, two feeding schemes were compared: sole use of either commercial feeds or the fishery by-catch items. In both cases, sufficient revenue was generated to cover the installation and operational costs during a single culture cycle. When commercial diets or bycatch items were used to feed the shrimp, the rates of return were estimated to be $56 \%$ or $79 \%$ of the initial investments, respectively. Clearly, these rates of return were acceptable even for a new venture with its associated high risk factor. 


\section{Social impact}

It is of utmost importance to bear in mind that the establishment of shrimp farming in the region may result in a new use of the aquatic environment, alter existing marketing channels and also create new opportunities for employment and profit. These changes may be socially and environmentally beneficial or they can disrupt the ecosystems and create significant economic inequalities if the benefits are captured by elite interests (Bailey et al., 1996). Aside from the obvious socio-economic returns related to the introduction of a new source of income, a positive effect of this new activity would be the fixation of fishermen families in their original communities. Another interesting aspect could be that fishing continues to be the fisherman's main occupation since daily tasks related to the farming of shrimp in the pen enclosures is frequently a part-time activity (usually taking less than one hour per day). Informal interviews indicated that this additional income has resulted in the ability to purchase additional productive equipment, repayment of past debts, and the ability to make home improvements.

Our experience has demonstrated that the active participation of women and children have sometimes turned this activity into a familyoperated venture. Under these conditions, farming the shrimp in the pen enclosures does not require major reorganization of the household as a production unit. Furthermore, the proximity of the fishermen's house to the culture pens facilitates a high degree of access and vigilance for the farming activity throughout the culture period. We have also noticed that those fishermen that have in agriculture a second income-generating activity are more prone to understand the basic principles of shrimp aquaculture and therefore are the first ones to become interested in the activity. Those who are exclusively fishers tend not to take shrimp farming seriously as a possible income-generating activity.

The shrimp in the estuary are an open access resource available to anyone with the means to catch them. This situation results in competition among the fishermen for the resource (Bailey et al., 1996). In a sense, the fishermen are, therefore, in a process of active competition, which may create problems of disunity. We have observed, however, that those fishermen participating in the pen culture project are starting to have a more positive perspective towards associative/cooperative work, which is significant, given the negative feelings that the fishermen often have toward collective work. Nevertheless, it is still very common that their first choices for partners are their relatives or old-time neighbors. The importance of direct commercialization and the actual value of their produce have also been perceived as issues often neglected by the fishermen. These aspects are contrary to the current situation where the price of the shrimp is basically decided by the middlemen and/or processing industry. Additionally, some fishermen are gradually realizing that they can also add value to the shrimp and consequently increase their income and, more importantly, create new employment opportunities within the community. It is also worth mentioning that by "controlling" part of the shrimp's life cycle, the fishermen have started to have a better understanding of the decisive role the environment plays in their lives and livelihood. The better understanding of the effect that the environment has on the shrimp has brought a greater awareness of the effect that environmental management has on the well-being of their families and communities.

\section{Environmental impacts}

Several of the issues associated with the "Green Revolution" that transformed the agricultural systems during the 1960's and 1970's are emerging again in relation to the "Blue Revolution" of aquaculture (Hannig, 1988). These include the promotion of intensive production systems that skew the benefits of development into the hands of a few. In many ways, however, the issues associated with aquacultural development are even more serious than those associated with the Green Revolution. Aquaculture often takes place in multiple use areas (bays, mangrove forests, estuaries, reservoirs, rivers, etc.). The introduction of shrimp farming into the estuarine area may thus represent a conversion of multiple use resources to single use property, which may pose serious consequences for the displaced individuals or groups in the future.

The farming of shrimp can also create environmental problems that can undermine the potential of a production system. The problems of declining water and sediment quality associated with intensive production may affect the surrounding environment. Intensive production systems crowd large numbers of shrimp into relatively small areas. High rates of feeding may 
be used, which may cause serious water and sediment quality problems. Poor environmental quality in turn stresses the shrimp, increasing the incidence of diseases and the risk of massive kills. In the 1980's and 1990's, several shrimp producing countries (Taiwan, Thailand, Indonesia and Ecuador) experienced widespread outbreaks of viral diseases due to the environmental quality problems created by the adoption of intensive production systems (New, 1996).

Studies evaluating the environmental conditions inside and outside $F$. paulensis pen enclosures found no significant differences in terms of the oxygen consumption, and nitrogen and phosphorus concentrations (Poersch et al., 2003; Poersch, 2004). However, differences in the diversity and abundance of the macrobenthic species were observed around the pens (Poersch et al., 2003; Poersch, 2004). Poersch (2004) reported that this kind of culture system had no influence on the water quality in its surroundings, but the higher abundance of the polychaeta Heteromastus similis near the pen $(1 \mathrm{~m})$ did demonstrate a small impact on the macrobenthic community. The impact (predation and/or disturbance) on the abundance of the macrobenthic invertebrate community was also recorded inside the pens, indicating different responses of the benthic species to the shrimp culture (Soares et al., 2004). Although the impact of shrimp farming in the pen enclosures is apparently limited to the fenced area and restricted to 3-4 months per year (Soares et al., 2004), results could have more relevance if the intensity of culture was increased, or if the number of pens located within the lagoon was to significantly increase.

The sediments collected from the shrimp culture pens had significantly lower levels of organic matter than those collected from surrounding areas within the lagoon due to shrimp grazing on the submerged vegetation (Esteves et al., 1999). Nevertheless, the mud and organic matter content did not differ across the sampled areas inside and outside the pens (Soares et al., 2004). These authors suggested that the pen culture preserved the sediment properties and the water circulation through the pens helped to maintain these parameters at similar levels to those observed from the adjacent area (outside pens). The choice of an indigenous species, which is obviously adapted to the local environment, and the application of relatively low stocking densities have proven important management tools in minimizing the impacts. The possible impacts usually linked to the introduction of exotic species, such as the introduction of previously non-existing diseases and parasites, competition or displacement of native species, could be avoided. Furthermore, the development of the technology and the use of a native species that is not cultured elsewhere exemplify the use and conservation of biodiversity.

In terms of the area available for the culture, as the total estuarine area has around 100,000 ha, a fraction less than $1 \%$ of the total estuarine area (1,000 ha) would allow the culture of shrimp in the pen enclosures by hundreds of fishermen families. However, as the carrying capacity of the estuary is not precisely understood, this aspect was studied in situ in parallel with the application of Geographic Information Systems (GIS) (Freitas and Tagliani, 2007). The main goals are to establish a limit number of culture structures that could be safely set and the definition of the more appropriate areas within the estuary. Another approach is to estimate the number of pen enclosures that each estuarine inlet would be able to hold without compromising its water quality. This has been dealt through the development of a mathematical model based on the potential discharge of the total nitrogen by the culture units under a very conservative scenario (Castello et al., 2008). According to this model, a total of 72 pen enclosures (each with an area of $3.100 \mathrm{~m}^{2}$ ) could be installed in the Saco da Mangueira, a 1,800 ha estuarine inlet, without significantly affecting the total nitrogen levels in the water.

Overall results have demonstrated that shrimp farming in the pen enclosures, when managed under the guidelines discussed here, would be ecologically sustainable (Esteves et al., 1999; Wasielesky et al., 2001a; Poersch et al., 2003; Poersch, 2004; Soares et al., 2004). However, as most of these studies have been performed with a small number of units and at a relatively short time scale, present research efforts are now considering these possible effects on a longer period of time.

\section{Constraints and possibilities}

Availability of $P L$

The future success of $F$. paulensis culture in southern Brazil and elsewhere will depend upon increasing the supplies of high quality seed for stocking the pen enclosures and perhaps even the farm ponds. Since the early 1980's, nauplii production of $F$. paulensis in Brazil has been 
based on the capture of wild broodstock in the coastal waters off Santa Catarina (Marchiori and Boff, 1983; Marchiori and Cavalli, 1993). The long-term development of any shrimp farming venture, however, will only be achieved with the complete control over the life cycle. In this regard, the domestication of $F$. paulensis and the consequent formation of captive stocks with selected characters, e.g. improved growth, adaptability to extreme culture conditions and resistance to common pathogens, would certainly be of benefit. However, current practices in the formation of the breeding stocks still rely almost completely on the supply of wild animals. Despite the supposedly advantageous performance of wild broodstock, the unpredictable supply and high capture costs might constrain the sustainable development of $F$. paulensis farming in the region. In this context, several studies have been carried out to optimize the maturation and reproduction of this species in captivity (Peixoto et al., 2002a, 2002b, 2003b, 2003c, 2004b), especially the evaluation of the domesticated broodstock as an alternative (Cavalli et al., 1997; Peixoto et al., 2003a, 2004a). The accelerated search to close the life cycle and improve the reproductive performance of $F$. paulensis in captivity will certainly contribute to the design of an efficient breeding program. An initial attempt to determine the genes related to growth performance using the DDRT-PCR (Differential display Reverse Transcription - Polymerase Chain Reaction) has been reported (Kamimura et al., 2008).

\section{Reaching the fishermen}

The state-run extension service has been responsible in establishing a link between the university and fishing communities. Generally, the scientists are not trained to express themselves using simple language skills and methods to reach the people with very basic levels of literacy. Furthermore, it has been observed that some communities are intimidated, at least at first sight, by the presence of the scientists in the neighborhood as they are mistakenly associated to the governmental agency (IBAMA) responsible for the fishery management. Therefore, the training of the extension staff is needed to effectively transfer the culture technology in order to breakdown the communication barriers with the community members, and encourage all the fishermen to participate in the process as cooperative workers. This learning and training process will develop a link extremely beneficial between the fishermen community, the general society and the university.

\section{Extension to other areas}

Although the pen culture of $F$. paulensis has been originally proposed to the fishermen community in the Patos Lagoon estuary, recent efforts have focused on extending this technology to other coastal lagoons in Brazil and neighboring countries. In the state of Santa Catarina (southern Brazil), the culture of $F$. paulensis in the pen enclosures has been developed in the Imaruí Lagoon, where the local research and extension service (EPAGRI) is responsible to monitor the culture activity and support local artisanal fishermen. A demonstrative project is also being carried out in the Armazém Lagoon, municipality of Tramandaí, Brazil. Similarly, a partnership between the University of Rio Grande and PROBIDES (Program of Biodiversity Conservation and Sustainable Development of the Eastern Aquatic Environments) has developed experimental pen enclosures for the artisanal fishermen community in the Rocha Lagoon, Uruguay. Preliminary results from the culture of $F$. paulensis in the pens in other coastal lagoons indicate that production levels similar to those observed in the Patos Lagoon estuary may be attained. Furthermore, these experiences have been important to evaluate the social impacts of the shrimp farming in different fishermen communities, as well as the potential environmental impacts in other aquatic ecosystems.

\section{CONCLUSION}

Overall, the present case represents a strong example of a locally developed shrimp farming system that is economically viable, socially valuable and ecologically sound. Nevertheless, it is also understood that to fully exploit its potential, it is necessary to take the current social structure and cultural context into consideration if the farming of $F$. paulensis in the estuary of Patos Lagoon and elsewhere is to succeed. 


\section{ACKNOWLEDGEMENTS}

Over the last decade, the development of this project has been supported by grants from $\mathrm{CNPq}$, CAPES, FAPERGS, RS-RURAL, SEAP/PR, Santander Banespa, Universidade Solidária, Fundación Avina, and the Secretariat of Science and Technology/RS. R.O. Cavalli, W. Wasielesky and S. Peixoto acknowledge the support as research fellows of CNPq.

\section{RESUMO}

O camarão-rosa Farfantepenaeus paulensis é considerado uma espécie com potencial para criação no estuário da Lagoa dos Patos, RS, onde o volume desembarcado deste recurso vem decrescendo nos últimos anos. A criação deste camarão em cercados está sendo proposta como uma fonte de renda alternativa para os pescadores artesanais e agricultores que habitam o entorno deste estuário. Do ponto de vista econômico, estes sistemas alternativos de criação apresentam vantagens sobre os sistemas tradicionais em viveiros de terra: não se necessita ter posse da terra, nem equipamentos de bombeamento d'água ou aeração. Além disso, materiais relativamente baratos são utilizados na construção das estruturas de engorda e há uma grande disponibilidade de alimento natural. Esta revisão apresenta alguns aspectos da criação de $F$. paulensis em cercados como uma alternativa às comunidades de pescadores. Maior ênfase será dada no desenvolvimento dos sistemas de criação, manejo, impactos sociais e ambientais, dificuldades e possibilidades.

\section{REFERENCES}

ABCC (Brazilian Shrimp Farmers' Association). (2004), A carcinicultura brasileira em 2003. Revista da $A B C C, \mathbf{6}, 30-36$.

Abdallah, P. R. (1998), Atividade pesqueira no Brasil: política e evolução PhD Thesis. Escola Superior de Agricultura, University of São Paulo, Piracicaba, Brazil.

Abdallah, P. R., Finco, M. V. A. and Wasielesky, W. J. (2003), Viabilidade econômica do cultivo de camarão em cercados e gaiolas no estuário da Lagoa dos Patos. Estudos and Debate, 10, 111-124.

Bailey, C., Jentoft, S. and Sinclair, P. (1996), Social science contributions to aquacultural development. In: Aquacultural development: Social dimensions of an emerging industry, eds. C. Bailey, S. Jentoft and P. Sinclair. Westview Press, Boulder, CO, USA, pp. 3-20.

Castello, J. P. (1985), La ecologia de los consumidores del estuario de la Lagoa dos Patos, Brasil. In: Fish Community Ecology in Estuaries and Costal Lagoons: Towards an Ecosystem Integration, ed. A. Yañez-Aracibia, UNAM Press, Mexico, pp. 383-406.

Castello, J.P. and Möller, O.O. (1978), On the relationship between rainfall and shrimp production in the estuary of the Patos Lagoon (Rio Grande do Sul, Brazil). Atlântica, 3, 67-74.

Castello, J. P., Poersch, L., Vasconcellos, M. C., Wasielesky ,W. and Cavalli, R. (2008), Rearing shrimp in pens: a predictive model for impact assessment. Estuaries and Coasts, 31, 215-222.

Cavalli, R. O., Scardua, M. P. and Wasielesky, W. J. (1997), Reproductive performance of different-sized wild and pond-reared Penaeus paulensis females. J. World Aquacult. Soc., 28, 260-267.

Cavalli, R. O., Wasielesky, W. J., Peixoto, S. and Santos, M. H. S. (2003), Estimating the best stocking density for the culture of Farfantepenaeus paulensis in pen enclosures. In: Book of Abstracts of the World Aquaculture Meeting, ed. World Aquaculture Society, Salvador, Brazil, p. 349.

Cavalli, R. O., Peixoto, S., Wasielesky, W. and Poersch, L. H. (2005), Guidelines proposed for the certification of organic penaeid shrimp in Brazil. Global Aquaculture Advocate, 8(2), 60-61.

CEPERG. (1999), Desembarque de pescado no Rio Grande do Sul: 1996-1998. Ministry of Environment - IBAMA, Special Publication, Brasilia, Brazil.

Costa, T. B. and Prentice C. (2003), Comparison of the quality of pink shrimp (Farfantepenaeus paulensis) from the artisanal fishery and culture system at Rio Grande, Brazil. In: Book of Abstracts of the World Aquaculture Meeting, ed. World Aquaculture Society, Salvador, Brazil, p. 208.

D'Incao, F. (1991), Pesca e biologia de Penaeus paulensis na Lagoa dos Patos, RS. Atlântica, 13, 159 177.

D'Incao, F., Valentini, H. and Rodrigues, L. F. (2002), Avaliação da pesca de camarões nas regiões Sudeste e Sul do Brasil. Atlântica, 24, 103-116.

Dolci, D., Wasielesky, W., Cavalli, R. O. and Silva, T. (1996), Desarrollo de estructuras para el cultivo del camaron rosado Penaeus paulensis en jaulas y corrales en el estuario de la Lagoa dos Patos, Brasil. In: Book of Abstracts of the Latin America Aquaculture Congress, ed. Asociacion Latinoamericana de Acuicultura, Coquimbo, Chile, pp. 140-143.

Domingos, J. A. S., Santos, M. H. S. AND Wasielesky, W. J. (2000), Cultivo do camarão rosa Farfantepenaeus paulensis (Decapoda: Penaeidae) em gaiolas utilizando como alimentos ração comercial e resíduos de pescado preservados em sal. In: Book of Abstracts of the Brazilian Symposium of 
Aquaculture, ed. ABCC - Brazilian Shrimp Farmers' Association, Florianópolis, Brazil. (CD-ROM).

Esteves, L. S., Wasielesky, W. J. and Lima, L. G. (1999), Alterações no teor de matéria orgânica nos sedimentos do estuário da Lagoa dos Patos decorrentes do cultivo de camarão em cercados. In: Book of Abstracts of the XII Semana Nacional de Oceanografia, ed. Associação Brasileira de Oceanografia, Rio de Janeiro, Brazil, p. 26.

Freitas, D. M. and Tagliani, P. R. A. (2007), Spatial planning of shrimp farming in the Patos Lagoon Estuary (Southern Brazil): an integrated coastal management approach. J. Coastal Res., 47, 136-140.

Hannig, W. (1988), Towards a Blue Revolution: Socioeconomic Aspects of Brackishwater Pond Cultivation in Java. Gadjah Mada University Press, Yogyakarta, Indonesia.

Kamimura M. T., Meier, K. M., Cavalli, R. O., Laurino, J., Maggioni, R. and Marins, L.F. (2008). Characterization of growth-related genes in the southwestern Atlantic pink shrimp Farfantepenaeus paulensis (Pérez-Farfante, 1967) through a modified DDRT-PCR protocol. Aquac. Res., 39, 200-204.

Marchiori, M. A. (1996), Guia ilustrado de maturação e larvicultura do camarão-rosa Penaeus paulensis Pérez-Farfante, 1967. FURG Press, Rio Grande, Brazil.

Marchiori, M. A. and Boff M.H. (1983), Induced maturation, spawning and larvae culture of the pink shrimp Penaeus paulensis Pérez-Farfante. Mems. Asoc. Latinoam. Acuicult., 5, 331-337.

Marchiori M. A. and Cavalli R. O. (1993), Commercial scale maturation of Penaeus paulensis in a semiclosed recirculation system. In: Proceedings of the Fourth Brazilian Symposium on Shrimp Culture, ed. MCR Aquicultura, João Pessoa, Brazil, pp. 385-398.

New, M. (1996), Sustainable global aquaculture. World Aquaculture, 27, 4-6.

Nunes, A. J. P. and Suresh, A.V. (2001), Marine shrimp farming in northeast Brazil. World Aquaculture, 32, 3236.

Paquotte, P., Chim, L., Martin, J. L. M., Lemos, E., Stern, M. and Tosta G. (1998), Intensive culture of shrimp Penaeus vannamei in floating cages: zootechnical, economic and environment aspects. Aquaculture, 164, 151-166.

Peixoto, S., Cavalli, R.O., D’Incao, F., Wasielesky, W. and Milach Â. (2002a), A comparative study of the ovarian histology of eyestalk ablated and unablated Farfantepenaeus paulensis after spawning. Bol. Inst.Pesca, 28, 71-76

Peixoto, S., Cavalli, R. O., D`Incao, F., Wasielesky, W. and Aguado N. (2002b), Description of reproductive performance and ovarian maturation of wild Farfantepenaeus paulensis from shallow waters in southern Brazil. Nauplius, 10, 149-153.

Peixoto, S., Wasielesky, W., D'Incao, F. and Cavalli R.O. (2003a), Reproductive performance of similarly- sized wild and captive Farfantepenaeus paulensis. J. World Aquacult. Soc., 34, 50-56.

Peixoto, S., Cavalli, R. O., D`Incao, F., Milach, Â. and Wasielesky, W. (2003b), Ovarian maturation of wild Farfantepenaeus paulensis in relation to histological and visual changes. Aquac. Res., 34, 1255-1260.

Peixoto, S., Cavalli, R. O. and Wasielesky, W. (2003c), The influence of water renewal rates on the reproductive and molting cycles of Penaeus paulensis in captivity. Brazilian Arch. Biol. Tech., 46, 281-286.

Peixoto, S., Cavalli, R. O., Wasielesky, W., D'Incao, F., Krummenauer, D. and Milach, Â. (2004a), Effects of age and size on reproductive performance of captive Farfantepenaeus paulensis broodstock. Aquaculture, 238, 173-182.

Peixoto, S., Cavalli, R. O., Krummenauer, D., Wasielesky, W. and D'Incao F. (2004b), Influence of artificial insemination on reproductive performance of Farfantepenaeus paulensis in conventional and unisex maturation systems. Aquaculture, 230, 197204.

Peixoto, S., Cavalli, R. O. and Wasielesky, W. (2005), Recent developments on broodstock maturation and reproduction of Farfantepenaeus paulensis. Brazilian Arch. Biol. Tech., 48, 997-1006.

Peña, R. and Prospero, O. (1984), Floating nursery cage for higher survival. Asian Aquac., 6, 06-08.

Pissetti, T. L. (2004), Efeitos da densidade de estocagem e do substrato artificial no cultivo do camarão-rosa Farfantepenaeus paulensis (Pérez-Farfante, 1967) em cercados. Master thesis in Aquaculture, FURG, Brazil.

Poersch, L., Wasielesky, W. J., Cavalli, R. O. and Castello, J. P. (2003), Culture of Farfantepenaeus paulensis in pen enclosures: impact on the surrounding benthic community. In: Book of Abstracts of the World Aquaculture Society Meeting, ed. World Aquaculture Society, Salvador, Brazil, p. 781.

Poersch, L. (2004), Aquacultura no estuário da Lagoa dos Patos e sua influência sobre o meio ambiente. Ph.D thesis in Biological Oceanography, FURG, Rio Grande, Brazil.

Reis, E. G. (1992), An assessment of the exploitation of the white croaker Micropogonias furnieri (Pisces, Scianidae) by the artisanal fisheries in coastal waters of southern Brazil. PhD Thesis. University of East Anglia, Norwich, England.

Reis, E. G., Vieira, P. C. and Duarte V. (1994), A pesca artesanal no estuário da Lagoa dos Patos e costa do Rio Grande do Sul. Atlântica, 16, 69-86.

Reis, E. G. and D'Incao, F. (2000), The present status of artisanal fisheries of extreme southern Brazil: an effort towards community-based management. Ocean Coast. Man., 43, 585-595.

Samaranayake, R. A. D. B. (1990), Pen culture trials with the tiger prawn, Penaeus monodon in Chilaw Lagoon, Sri Lanka. In: Proceedings of the Second 
Asian Fisheries Forum, ed. Asian Fisheries Society, Manila, pp. 107-108.

Santos, M. H. S., Santos, E.A. and Wasielesky, W. J. (2000), Avaliação do emprego de resíduos de pescado, espécies rejeitadas e ração comercial em sistemas alternativos de cultivo do Farfantepenaeus paulensis, no extremo sul do Brasil. In: Book of Abstracts of the Brazilian Symposium of Aquaculture, ed. Brazilian Shrimp Farmers' Association, Florianópolis, Brazil (CD-ROM).

Santos, M. H. S., Santos, R. L., Wasielesky, W.J. and Santos E.A. (2001), Response of juvenile pink shrimp Farfantepenaeus paulensis to natural food items and commercial pelleted diet. In: Book of Abstracts of the World Aquaculture Society Meeting, ed. World Aquaculture Society, Orlando, USA, pp. 397.

SEAFDEC (Southeast Asian Aquaculture and Fisheries Development Center). (1979), Cage farming of prawn (P. monodon) in fresh water. Asian Aquac., 7, 4-5.

Soares, R., Peixoto, S., Bemvenuti, C., Wasielesky, W., D'Incao, F., Murcia, N. and Suita, S. (2004), Composition and abundance of invertebrate benthic fauna in Farfantepenaeus paulensis culture pens (Patos Lagoon estuary, southern Brazil). Aquaculture, 239, 199-215.

Tookwinas, S. (1990), Pen culture techniques of marine shrimp in Thailand. Infofish Int., 2, 38-40.

Tsuzuki, M., Cavalli, R. O. and Bianchini, A. (2000), The effects of temperature, age, acclimation to salinity on the survival of Farfantepenaeus paulensis postlarvae. J. World Aquac. Soc., 31, 459-468.

Von Ihering, H. (1885), Os peixes da costa do mar no Estado do Rio Grande do Sul. In: Anuário do Estado do Rio Grande do Sul para o ano 1897. Porto Alegre, Brazil, pp. 98-124.
Walford, J. and Lam, T. J. (1987), Floating hatchery and net cage culture of Penaeus indicus in the straits of shore, Singapore. Aquaculture, 62, 11-32.

Wasielesky, W., Cavalli, R. O., Dolci, D. and Silva, T.M.S. (1995), Crescimento do camarão-rosa Penaeus paulensis (Crustacea: Decapoda) em gaiolas e cercados no estuário da Lagoa dos Patos. In: Anais do VI Encontro Riograndense de Técnicos em Aqüicultura, ed. Zimmerman, S., Editora da UFRGS, Porto Alegre, Brazil, pp. 14-25.

Wasielesky, W., Peixoto, S., Jensen, L., Poersch, L. H. and Bianchini, A. (2001a), Preliminary study of the pink shrimp Farfantepenaeus paulensis in pen enclosures in Patos Lagoon estuary. Bol. Inst. Pesca, 30, 63-70.

Wasielesky, W., Poersch, L. H., Jensen, L. and Bianchini, A. (2001b), Effect of stocking density on pen reared pink shrimp Farfantepenaeus paulensis (PérezFarfante, 1967) (Decapoda, Penaeidae). Nauplius, 9, 163-167.

Wasielesky, W., Peixoto, S., Santos, M. H. S. and Cavalli R.O. (2002), Cultivo do camarão rosa como alternativa de geração de renda. In: Extensão Universitária: Ação Comunitária em UniversidadesBrasileiras, eds. Calderón A.I. and Sampaio H., Olho d’Água, São Paulo, Brazil, pp 1727.
Received: April 17, 2006; Revised: July 26, 2007; Accepted: March 11, 2008 